\title{
新潟西海岸における潜堤背後の断面変化に関する数值計算
}

\section{Prediction of Beach Profile Change behind Submerged Breakwater on the Niigata-West Coast}

\author{
栗山善昭 ${ }^{1} \cdot$ 竹村淳 ${ }^{2} \cdot$ 水口幸司 $^{3} \cdot$ 松井康彦 ${ }^{4}$ \\ Yoshiaki KUIRIYAMA, Jyunichi TAKEMURA, Koji MINAKUCHI and Yasuhiko MATSUI
}

\begin{abstract}
The numerical model for predicting the beach profile change behind a submerged breakwater on the Niigata-West coast was developed. The model estimates the beach profile change on the basis of the cross-shore gradient of crossshore sediment transport rate consisting of suspended load due to wave breaking and bed loads due to wave nonlinearity and beach slope. The model was calibrated with the beach profile change on the Niigata-West coast during a one-year period from July 2001 to July 2002. Numerical simulations using the model shows that the increase in the crown height of the submerged breakwater is effective in reducing the foreshore erosion and in making the sediments transported seaward from the eroded foreshore remain in the inner surf zone.
\end{abstract}

\section{1. はじめに}

潜堤は景観上の優れた機能を有していることから，海 岸防護においてその整備が進んでいる。 その一方で, 潜 堤は, 単位幅（岸沖方向）当たりの波浪減衰効果が小さ いなどの弱点を有しており，そのため, 潜堤背後の海浜 は必ずしも十分に安定しているわけではない.そこで, 本研究では, 潜堤背後の断面変化を予測するモデルの開 発を目的とし，砂州の移動を再現するために開発された モデル（Kuriyama，2010）を新潟西海岸の潜堤背後の地 形変化に適用し, その現地再現性を検討するとともに, そのモデルを用いて潜堤の天端高さが断面変化に与える 影響を検討した。

\section{2. 新潟西海岸の概要}

信濃川河口の西側に位置する新潟西海岸（図-1）では, 河川改修工事（1875～1903年）や導流堤建設（1897～ 1924年), 大河津分水の通水 (1922年), 関屋分水の通水 (1972年), 地下水のくみ上げによる地盤沈下（1960年代 以降）などの影響により，1900年代より海岸侵食が進行 し，1948年には，1889年と比較して最大で $350 \mathrm{~m}$ の汀線 の後退が生じた.

そのため, 1960年代より離岸堤が整備され，離岸堤建 設後は, 汀線近傍の海浜は防護された。しかし, それよ り沖では海岸侵食が進行したため, その対策が検討され, 新たに設置する構造物の沖で侵食が発生しないよう, 低 反射率の構造物である潜堤が採用されることとなった。

\begin{tabular}{|c|c|c|}
\hline $\begin{array}{l}\text { 正会員 } \\
\text { 正会 }\end{array}$ & 博(工） & $\begin{array}{l}\text { (独法)港湾空港技術研究所 海洋・水工部 } \\
\text { 新潟港湾·空港整備事務所長 } \\
\text { 新潟港湾空港技術調查事務所長 } \\
\text { 新潟港湾・空港整備事務所海岸課長 }\end{array}$ \\
\hline
\end{tabular}

さらに，潜堤背後の沿岸方向の流れによる底質の移動 量を軽減するための突堤と, 砂浜によって波浪エネルギ 一を減衰させるとともに新たな親水空間を創出するため の養浜とが海岸整備に加えられ, 全体としては面的防護 工法（砂浜を含む複数の海岸保全施設を組み合わせた海 岸保全工法）による海岸保全が計画された。突堤, 潜堤 の建設はそれぞれ1988年, 1989年より開始され, 養浜は 1994年から開始された.

以上の海岸整備により, 既存離岸堤の沖側で生じてい た大規模な侵食は収まったものの, 潜堤より岸側におい て小規模な侵食が継続しており（吉田ら，2008），その 值は単位沿岸幅あたり約 $20 \mathrm{~m}^{3} / \mathrm{year}$ である.

\section{3. 数値計算}

\section{（1）断面変化モデルの概要}

本研究で用いる断面変化予測モデルは, 主として沿岸 砂州の移動を再現するために開発されたものであり, 波 浪 - surface roller変形, 㞍り流れ速度推定, 沿岸流速推 定, 岸沖方向流速の非線形性を表すパラメーター推定, 断面変化の5つのサブモデルより構成されている.

波浪・surface roller変形サブプログラムにおいては, 自乗平均波高 $H_{r m s}$ の変形を計算する. Thornton · Guza （1983）と同様に，砕波帯内を含む計算領域全域におい て波高の確率密度関数としてレーリー分布を仮定すると ともに，确波波高以上の波が減衰すると仮定する.

挽波波高は合田（1970）の砕波公式を自ら取得した実 験デー夕を基に修正した木村・瀬山（1986）の式（1） より求める.

$$
\begin{aligned}
\frac{H_{b}}{h_{b}}=C_{b r} & {\left[0.16 \frac{L_{0}}{h_{b}}\left\{1-\exp \left[-0.8 \pi \frac{h_{b}}{L_{0}}\left(1+15 \tan ^{4 / 3} \beta\right)\right]\right\} \cdots(1)\right.} \\
& -0.96 \tan \beta+0.2]
\end{aligned}
$$




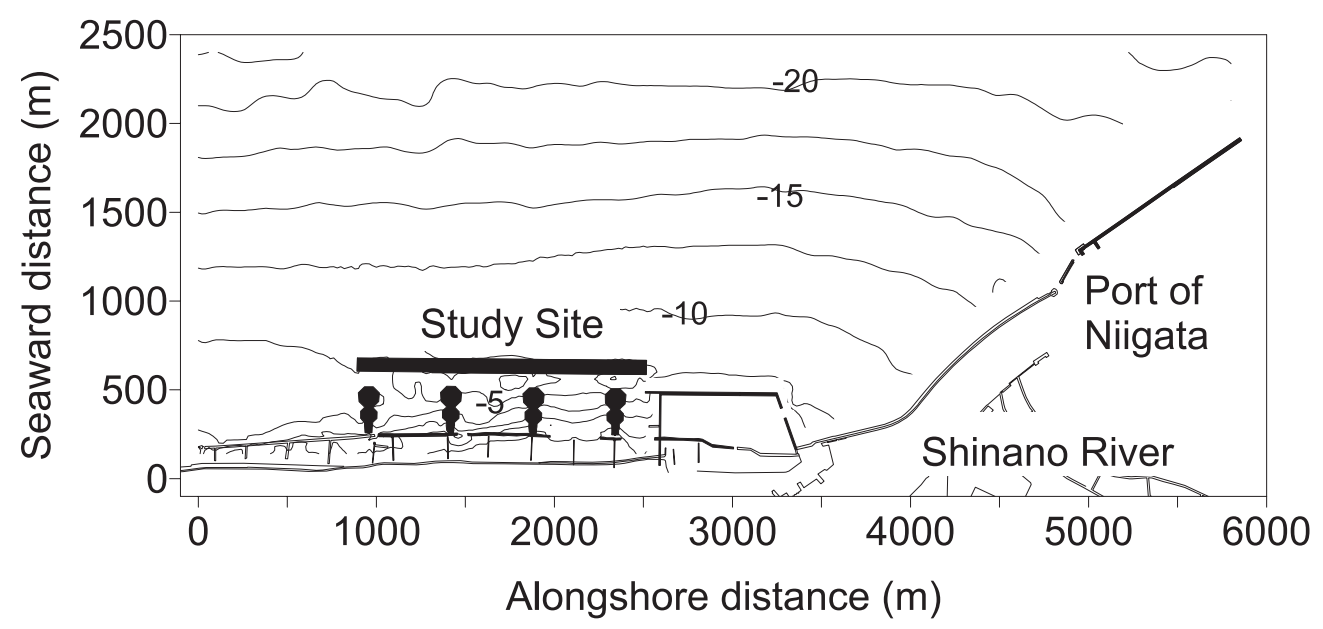

図-1 新潟西海岸の地形と構造物の位置（2008年7月）

ここで, $H_{b}$ は砕波波高, $h_{b}$ は碀波水深, $C_{b r}$ は無次元係 数, $L_{0}$ は沖波波長, $\tan \beta$ は海底勾配である. 無次元係数 $C_{b r}$ は実験デー夕を基にしている式（1）を現地に適用す るためにKuriyama・Ozaki（1996）が導入したものであ る. 海底勾配は沖向きに水深が大きくなる傾きを正と定 義するとともに, 計算地点を挟む $30 \mathrm{~m}$ の区間の平均勾配 とした。

砕波による波浪減衰は，式（2）に示すように， Thornton・Guza（1983）のボアモデルより求まる波浪工 ネルギーの減衰量 $B(H)$ に波高の確率密度関数 $P(H)$ を乗 じた值の積分として求める. 具体的には, $H_{b} \sim 3 H_{b}$ の範 囲を20区間に分割し，それぞれの区間の代表波高に対し て波浪減衰量を計算する。なお，最も大きい代表波高の 確率密度は, $3 H_{b}$ よりも大きい波高の出現確率も含むも のとする.

$$
\begin{aligned}
& \frac{\partial E_{w} C_{g} \cos \theta}{\partial x}=\int_{H_{b}}^{\infty} P(H) B(H) d H \\
& B(H)=\frac{1}{4} \rho g \frac{1}{T} \frac{\left(B_{w} H\right)^{3}}{h}
\end{aligned} .
$$

ここで， $E_{w}$ は波浪エネルギー， $C_{g}$ は群速度， $x$ は沖方向 距離, $\theta$ は波向, $\rho$ は海水の密度, $g$ は重力加速度, $T$ は 周期, $H$ は波高, $h$ は水深である. 式 (2) の無次元係数 $B_{w}$ は, Kuriyama・Ozaki（1996）が木村ら（1998）の実 験デー夕を基に式（3）のように公式化した.

$$
B_{w}=C_{B}\left\{1.6-0.12 \ln \left(H_{0} / L_{0}\right)+0.28 \ln (\tan \beta)\right\}
$$

ここで, $H_{0}$ は沖波波高， $C_{B}$ は式 (1) の $C_{b r}$ と同様に実験 室デー夕を基にした式（3）を現地に適用するための無 次元係数である.

断面変化サブモデルでは, 岸沖漂砂量の岸沖勾配によ って断面変化が生ずると仮定しており, 岸沖漂砂量は以
下に示す 4 つの成分，すなわち，砕波によって浮遊した 底質が戻り流れで沖向きに輸送される浮遊砂量 $Q_{s}$, 流速 波形の上下の非対称性による岸向き掃流砂量 $Q_{b}, v$, 流速 波形の前後の非対称性による岸向きの掃流砂量 $Q_{b}, a$, 海 底勾配による漂砂量 $Q_{b}$, slope, から構成されている.

浮遊砂量の計算（式（4)）においては, Kobayashiら （2008）にならい，浮遊する底質の量がsurface rollerの工 ネルギー減衰量に比例すると仮定している，流速の上下 の非対称性による掃流砂量（式（5)）はBailard（1981） の式を, 流速の前後の非対称性による掃流砂量（式 (6)) はHoefel • Elgar（2003）の式を，海底勾配による掃流砂 量（式（7）はBailard（1981）の式を基にしている.

$$
\begin{aligned}
& Q_{s}=\alpha_{1} \frac{D_{r}}{\rho g(s-1) w_{f}} U \\
& Q_{b, v}=-\alpha_{2}\left(\left(\sqrt{\beta_{1}}\right)_{u} u_{b, r m s}^{3} \cos \theta+\right. \\
& \left.\left(u_{b, r m s}^{2}+u_{b l, r m s}^{2}\right) V \sin \theta \cos \theta\right) \\
& Q_{b, a}=-\alpha_{3}\left(\left(\beta_{3}\right)_{u} a_{b, r m s}-a_{c r}\left|\left(\beta_{3}\right)_{u}\right| /\left(\beta_{3}\right)_{u}\right) \cos \theta, \\
& \left|\left(\beta_{3}\right)_{u} a_{b, r m s}\right|>a_{c r} \cdots(6) \\
& Q_{b, a}=0, \\
& \left|\left(\beta_{3}\right)_{u} a_{b, r m s}\right| \leq a_{c r} \\
& Q_{b, s l o p e}=\alpha_{4} \frac{\tan \beta}{\tan \phi}\left(u_{b, r m s}^{3}+u_{b l, m s}^{3}\right)
\end{aligned}
$$

ここで， $\alpha_{1}$ は無次元係数， $D_{r}$ は surface rollerのエネルギ 一減衰率, $s$ は底質の比重, $w_{f}$ は底質の沈降速度, Uは戻 り流れ速度, $\alpha_{2}$ は $\mathrm{s}^{2} / \mathrm{m}$ の次元を持った係数, $\left(\beta_{1}\right)^{1 / 2}{ }_{u}$ は流 速の skewness, $u_{b}, r m s$ は底面流速の振幅, $u_{b l}, r m s$ は長周期 波による底面流速の振幅, $V$ は沿岸流速, $\alpha_{3}$ は $\mathrm{ms}$ の次元 を持った係数, $\left(\beta_{3}\right)_{u}$ は流速の atiltness (加速度の skewness), $a_{b}, r m s$ は底面における加速度の振幅, $a_{c r}$ は底質の移動限界 
加速度 $\left(=0.2 \mathrm{~m} / \mathrm{s}^{2}\right), \quad \alpha_{4}$ は $\mathrm{s}^{2} / \mathrm{m}$ の次元を持った係数， $\phi$ は 内部摩擦角（=30 degree）である.

\section{(2) 現況再現計算}

新潟西海岸における計算では, 第 1 突堤と第 2 突堤と に挟まれた領域（図-2）に扮いて既存の離岸堤や突堤が 無い領域（沿岸方向距離 $2000 \mathrm{~m} \sim 2060 \mathrm{~m}$ 及び $2140 \mathrm{~m}$ $2200 \mathrm{~m} ）$ の平均断面を対象とし, 潜堤の天端高さは $2.5 \mathrm{~m}$ とした．平均断面の一例として，2008年7月の断面を図3 に示す.

現況再現計算においては，まず，波浪・surface roller 変形サブプログラムにおける式（1），（3）に含まれる係 数 $C_{b r}, C_{B}$ を潜堤周辺での波浪観測結果を基に決定した. 続いて, 式（4）～(7) で表される4つの漂砂量に含まれ る係数 $\alpha_{1} \sim \alpha_{4}$ を 2001 年 7 月から 2002 年 7 月までの 1 年間 の断面変化を基に決定した.

\section{(a) 波浪変形計算}

係数 $C_{b r}, C_{B}$ を決定する際に用いる波浪デー夕は, 2008年 11 月～2009年 2 月に新淇港 - 空港整備事務所に よって潜堤の沖と岸で取得されたものである．潜堤より も岸における観測地点（St.1 とSt.2）の位置は図-2に示す 通りであり, 沖での観測地点の位置は沖方向距離 $x=$ 1220mである.

計算に抢ける沖側境界は沖の波浪観測地点 $(x=1220 \mathrm{~m})$ とし, 計算格子幅は $5 \mathrm{~m}$, 波向は汀線に対して直角方向と した。観測地点St.1 とSt.2 に打ける実測值と計算値との誤 差が最小となるように決定された係数の值は， $C_{b r}=0.7$,

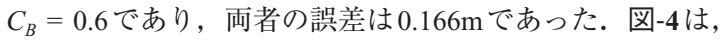
両者の相関を示したものであり，両観測地点ともに実測 波高が $2 \mathrm{~m}$ よりも小さいと推定值が実測值を上回り，大 きいと推定值が実測值を下回る傾向があるものの，モデ

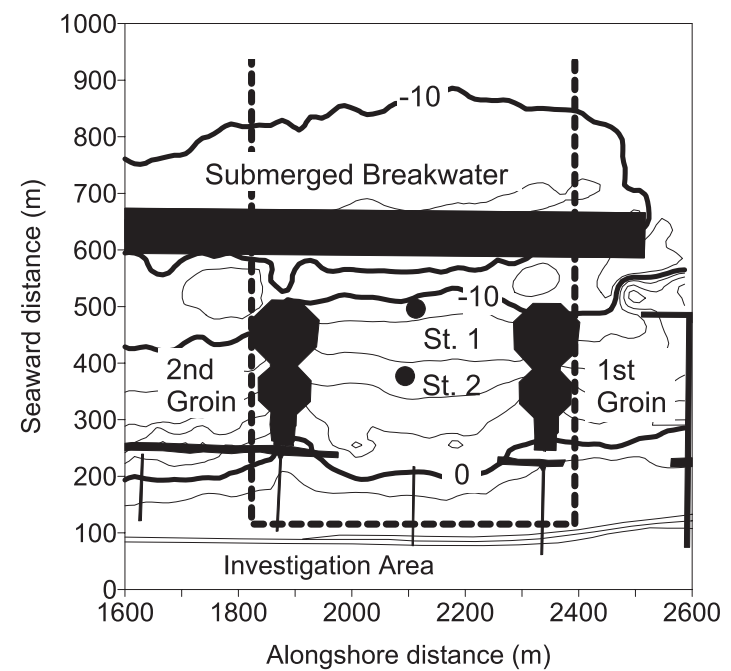

図-2 検討範囲における地形と構造物の位置および波浪観測 地点の位置

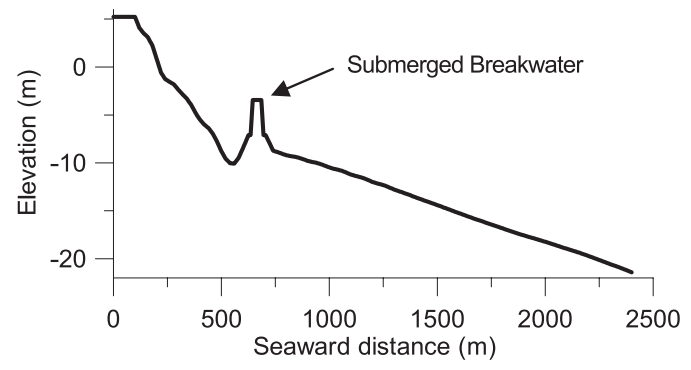

図-3 新潟西海岸における2008年7月の平均断面

ルは，潜堤背後の波浪変形を精度良く推定していること がこの図からうかがえる，なお，推定值と実測值との上 記の誤差の原因としては，モデルでは海底面および潜堤 天端での摩擦による波浪減衰を考慮していないことが考 えられる。

\section{(b) 断面変化計算}

式（4）～(7) で表される4つの漂砂量に含まれる係数 $\alpha_{1} \sim \alpha_{4}$ を新潟西海岸における2001年7月から 2002年7月 までの 1 年間の断面変化を基に, $x=100 \sim 400 \mathrm{~m}$ の範囲に おける地盤高さの実測值と計算值との誤差が最小となる ようにSCE-UA（Shuffled Complex Evolution - University of Arizona）法（Duan ら，1993 ; 土木学会，2000）を用 いて決定した。
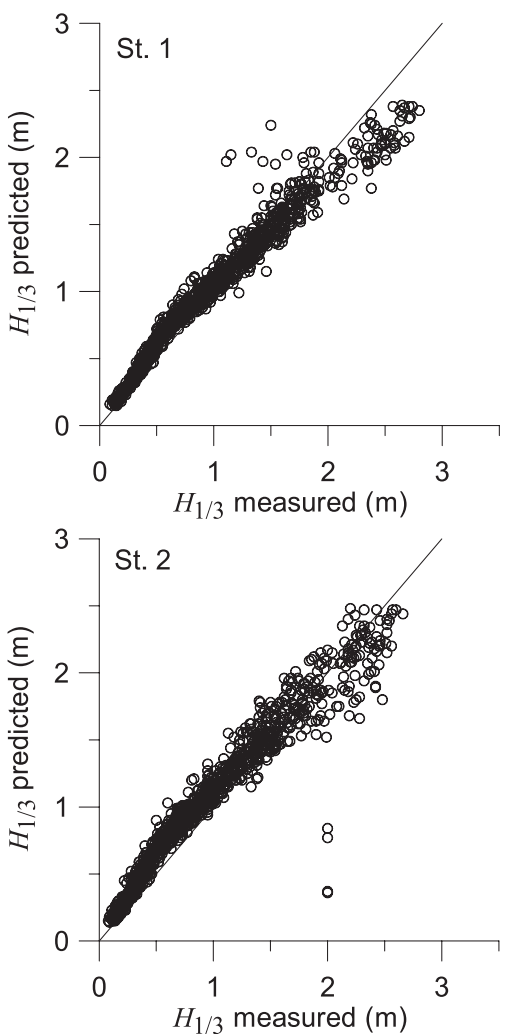

図-4 St.1 とSt.2における有義波高の実測値と計算值との比較 
計算では, 沖側境界を $x=2400 \mathrm{~m}$ の水深約 $22 \mathrm{~m}$ の地点 （図-3）に設定するとともに，格子間隔を $5 \mathrm{~m}$, 時間間隔 を 2 時間とし, 地形変化の計算は潜堤より岸側のみで行 った. 沖側境界の波高 - 周期は新潟沖の水深約 $35 \mathrm{~m}$ の地 点で取得されている沖波データから浅水係数を考慮して 推定した值とし, 波向は汀線に対して直角と仮定した.

計算の結果求まった係数の值は, $\alpha_{1}=2.0 \times 10^{-4}, \alpha_{2}=$ $8.17 \times 10^{-5} \mathrm{~s}^{2} / \mathrm{m}, \quad \alpha_{3}=1.42 \times 10^{-5} \mathrm{~m} / \mathrm{s}, \quad \alpha_{4}=5.079 \times 10^{-4} \mathrm{~s}^{2}$ $/ \mathrm{m}$ であった。図-5 はキャリブレーション期間である 2001 年から 2002 年までの断面変化とその後の 2008 年までの 断面変化を示したものであり, 図-6は2001年から2008年 までの期間の平均の岸沖漂砂量の岸沖分布を示したもの である。

モデルは, $x=150$ ～200mの領域の漂砂量を沖向きに 過大評価しているものの, 前浜 $(x=150 \sim 220 \mathrm{~m})$ の侵 食は良く再現している. 一方， $x<150 \mathrm{~m}$ における遡上波 あるいは飛砂によると考えられる堆積は計算では再現で きておらず，さらに，計算では，前浜から沖に輸送され た土砂の一部が $x=230 \mathrm{~m}$ 付近に堆積することにより, 実 測には無い小さな堆積領域が生じるとともに, それより 沖がやや急勾配となっている。 また, 図面は示さないも のの, $x>300 \mathrm{~m}$ では, 実測では沖向き漂砂量が増大し, 断面が侵食されているのに対して, 計算では, $x=300 \mathrm{~m}$ から 400mにかけて沖向き漂砂が減少し, 堆積が生じて いる.

実測と計算との間には上記の差があるものの，モデル の精度を表す Brier skill score（実測と計算が一致すると score $=1$, 対象モデルが初期地形から変化しないと仮定 するモデルよりも精度が悪いと score < 0） は2008年 7 月 で 0.16 であり，本モデルは現地における潜堤背後の断面 変化をおおむね再現していると言える.

モデルが $x>300 \mathrm{~m}$ での侵食を再現できなかった理由の 一つとして, 潜堤背後での沿岸流の発達が考えられる. 潜堤背後では平均水位の上昇により沿岸流が発達しやす く，この沿岸流によって底質が移動しやすくなり，底質 が戻り流れによって沖に流出した可能性がある。ただし， 検討領域は岸から $x=500 \mathrm{~m}$ 付近まで延伸された突堤で囲 まれているため, 沿岸流の影響が $x>300 \mathrm{~m}$ の断面変化に, どの程度影響を与えたかは不明であり, 今後, 流れと地 形変化に関する現地データや3 次元地形変化の数值シミ ユレーション結果による検討が必要である.

本キャリブレーションで得られた係数の值を茨城波崎 海岸の砂州移動を中心とした断面変化を基に得られた係 数の值（Kuriyama，2010）と比較してみると, 海底勾 配による漂砂量の係数 $\alpha_{4}$ に関しては, 本研究での值 $\left(5.079 \times 10^{-4} \mathrm{~s}^{2} / \mathrm{m}\right)$ は波崎での值 $\left(7.755 \times 10^{-4} \mathrm{~s}^{2} / \mathrm{m}\right)$ の 約 $2 / 3$ であった。一方, それ以外の漂砂量の係数である $\alpha_{1} \sim \alpha_{3}$ に関しては, 本研究での值 $\left(\alpha_{1}=2.0 \times 10^{-4}, \alpha_{2}\right.$ $\left.=8.17 \times 10^{-5} \mathrm{~s}^{2} / \mathrm{m}, \quad \alpha_{3}=1.42 \times 10^{-5} \mathrm{~m} / \mathrm{s}\right)$ は波崎での值（ $\alpha_{1}$ $\left.=1.147 \times 10^{-3}, \quad \alpha_{2}=7.651 \times 10^{-4} \mathrm{~s}^{2} / \mathrm{m}, \quad \alpha_{3}=9.96 \times 10^{-5} \mathrm{~m} / \mathrm{s}\right)$ に比べて非常に小さかった $(1 / 6 \sim 1 / 9)$. この原因は現 段階では不明であり，この点についても今後の検討が必 要である。

\section{（3）潜堤の天端高さが断面変化に与える影響}

潜堤の天端高さ $h_{c}$ を $-2.0 \mathrm{~m},-1.5 \mathrm{~m}$ とし，2001年 7 月の 断面を初期断面として 2008 年7月までの計算を行った. 図-7は断面変化に関する, 図-8は岸沖漂砂量の岸沖分布 に関する計算結果の比較を示したものである．潜堤の天 端高さを高くすると, 前浜の侵食量がやや減少するとと もに, $x=200 \mathrm{~m}$ 付近から沖向き漂砂量が減少し（図-8）, 前浜で侵食された土砂が $x=230 \sim 270 \mathrm{~m}$ の領域（地盤高 さ $0 〜-2 \mathrm{~m}$ ）に留まる結果となった（図-7）。ただし，現 況再現時 $\left(h_{c}=-2.5 \mathrm{~m}\right)$ における $x>200 \mathrm{~m}$ の領域での沖向 き漂砂量の増加量の計算值は現地の值よりも小さいので (図-6,8), $x=230 \sim 270 \mathrm{~m}$ の領域における実際の堆積量 は図-7に示されている計算算結果よりも小さい可能性が ある。

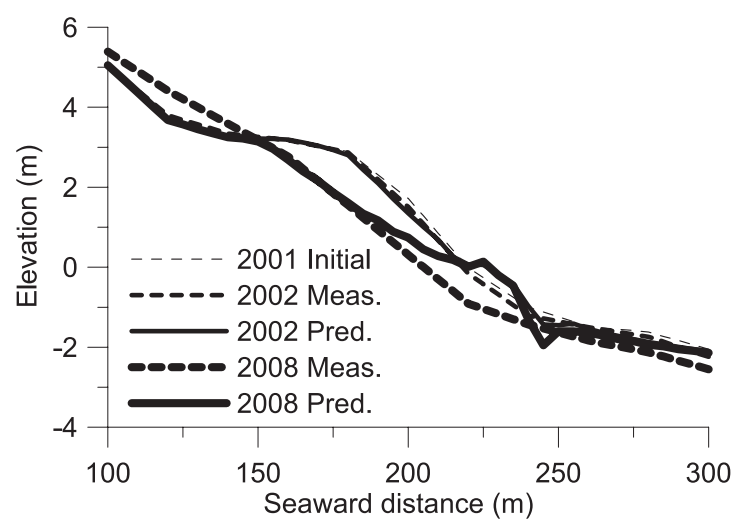

図-5 断面変化に関する実測值と計算値との比較

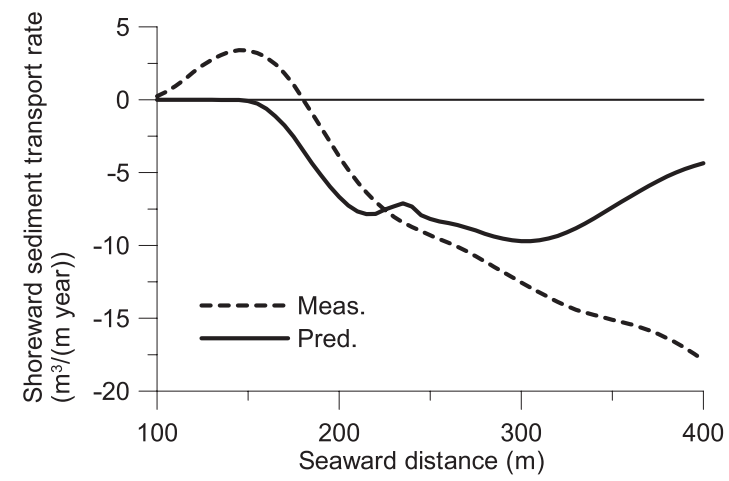

図-6 2001〜2008年の岸沖漂砂量の岸沖分布に関する実測值 と計算值との比較. 岸向きが正. 


\section{4. おわりに}

新潟西海岸の潜堤背後における2001年7月から 2002年 7 月までの 1 年間の沖方向距離 $x=100 \mathrm{~m} \sim 400 \mathrm{~m}$ の領域 （地盤高さ $5 \sim-5 \mathrm{~m}$ ）の断面変化を用いてキャリブレーシ ヨンを行った断面変化モデルは， $x=150 〜 200 \mathrm{~m}$ の領域 にける漂砂量を沖向きにやや過大評価しているものの, 前浜 $(x=150 \sim 220 \mathrm{~m})$ の侵食は良く再現した. しかし， 計算では, 前浜から沖に輸送された土砂の一部が $x=$ $230 \mathrm{~m}$ 付近に堆積することにより，実測には無い小さな堆 積領域が生じるとともに，それより沖がやや急勾配とな った。モデルの精度を示す Brier skill scoreは2008年7月

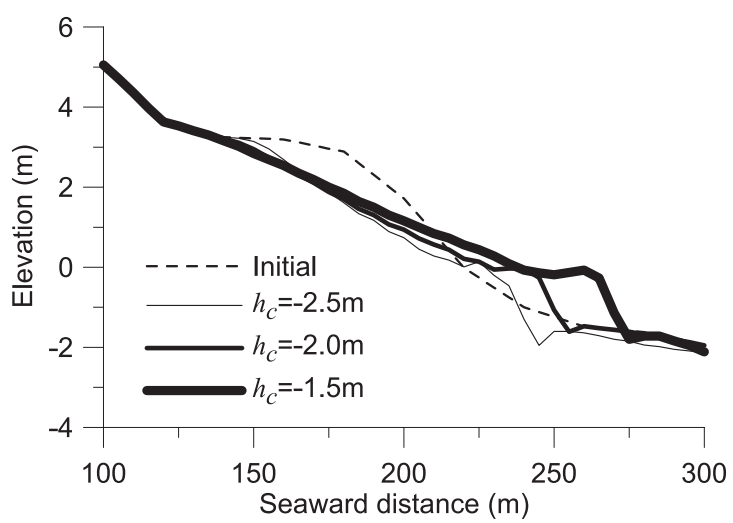

図-7 潜堤の天端高さを変化させた時の断面変化の比較

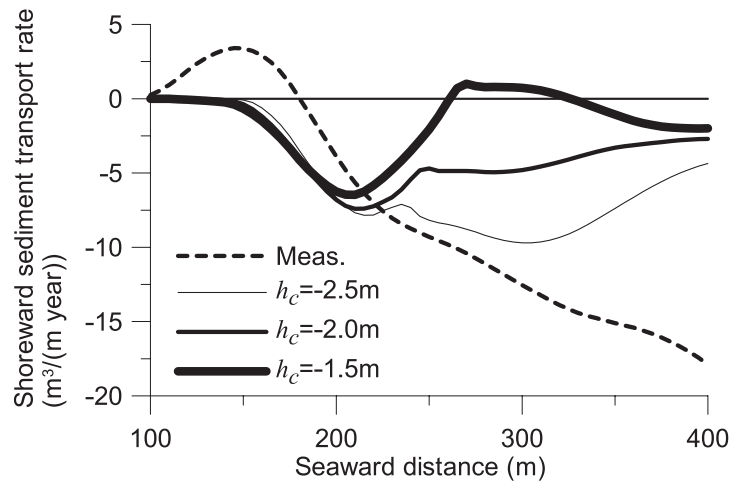

図-8 潜堤の天端高さを変化させた時の岸沖漂砂量の岸沖分 布の比較. 岸向きが正.
で 0.16 であり, 本モデルは現地における潜堤背後の断面 変化をおおむね再現していると言える。

このモデルを用い，潜堤の天端高さを変化させて断面 変化を計算したところ, 潜堤の天端高さを高くすると, 前浜の侵食量がやや減少するとともに, $x=200 \mathrm{~m}$ 付近か ら沖向き漂砂量が減少し, 前浜で侵食された土砂が $x=$ 230〜 270m（地盤高さ0〜-2m）に留まる結果となった.

謝辞：本研究で使用した沖波データは国土交通省新潟 湾・空港整備事務所と当所海象情報研究チームより提供 されたものである.ここに記して謝意を表する。

\section{参 考 文 献}

木村 晃, 瀬山 明（1986）：斜面上の不規則波の砕波限界に ついて，第33回海岸工学講演会論文集，pp.174-178.

木村 晃，後藤克史，瀬山 明（1988）：浅海域における不規 則波の波高変化について, 第35回海岸工学講演会論文集, pp. $168-172$.

合田良実（1970）：砕波指標の整理について，土木学会論文報 告集，第180号, pp.39-49.

土木学会 応用力学委員会 逆問題小委員会 (2000) : 土木工 学に扔ける逆問題入門，土木学会，158p.

吉田秀樹 - 清水利浩 - 伊部知徳 - 山田貴裕 - 片野明良 (2008)：大規模潜堤背後の海浜地形の特徵と地盤沈下に よる断面変化，海岸工学論文集，第 55 巻，pp.751-755

Bailard, J.A. (1981) : An energetics total load sediment transport model for a planar sloping beach, J. Geophys. Res, Vol.86, No.C11, pp. 10,938-10,954.

Duan, Q. Y., V. K. Gupta and S. Sorooshian (1993) : Shuffled complex evolution approach for effective and efficient global minimization, J. Optimization Theory and Applications, Vol. 73 , No. 3, pp. 501-521.

Hoefel, F. and S. Elgar (2003) : Wave-induced sediment transport and sandbar migration, Science, 299, pp. 1885-1887.

Kobayashi, N., A. Payao and L. Schmied (2008) : Cross-shore suspended sand and bedload transport on beaches, J. Geophys. Res., Vol.113, C07001, doi:10.1029/2007JC004203.

Kuriyama, Y. and Y. Ozaki (1996) : Wave height and fraction of breaking waves on a bar-trough beach -Field measurements at HORS and modeling-, Rep. Port and Harbour Res. Inst., Vol.35, No.1, pp.1-38, 1996.

Kuriyama, Y. (2010) : Numerical simulation of cyclic seaward bar migration, Rep. Port and Airport Res. Inst., Vol.49, No. 2. (in press)

Thornton, E. B. and R. T. Guza (1983) : Transformation of wave height distribution, J. Geophys. Res., Vol.88, No.C10, pp.59255938 . 